\title{
Achnanthidium delmontii sp. nov., a new species from French rivers
}

\author{
Florence PÉRÈs $^{1 *}$, A. Barthès ${ }^{1,2}$, Etienne Ponton ${ }^{1}$, Michel Coste $^{3}$, Loïc Ten-Hage ${ }^{2}$ \\ \& René $\mathrm{LE}-\mathrm{COHU}^{2}$
}

\author{
${ }^{1}$ Asconit Consultants, Site Naturopole - 3, Boulevard de Clairfont, 66350 Toulouges - France; *Corresponding \\ authore-mail: florence.peres@asconit.com \\ ${ }^{2}$ Université de Toulouse, INP, UPS, EcoLab (Laboratoire Ecologie Fonctionnelle et Environnement), 118 Route \\ de Narbonne, 31062 Toulouse, France \\ ${ }^{3}$ Cemagref U.R. REQE (Réseaux, Epuration et Qualité) - Groupement Cemagref de Bordeaux \\ 50, Avenue de Verdun, 33612 Cestas cedex - France
}

\begin{abstract}
A new freshwater diatom species belonging to the genus Achnanthidium KüTz. has been found in several French rivers namely those of the Languedoc-Roussillon and Rhin-Meuse regions. Achnanthidium delmontii sp. nov. is described based on light and scanning electron microscopy observations. This species belongs to the group of Achnanthidium taxa with terminal raphe fissures curved to the same side of the valve and it is compared to the most related species: Achnanthidium pfisteri LANGE-BERTALOT, Achnanthidium pyrenaicum (HuSDEDT) KOBAYASI, Achnanthidium temniskovae IvANov et EcTOR and Achnanthidium zhakovschikovii POTAPOVA. The assessment of its ecology was made through physicochemical analysis carried out on sites which are part of water quality monitoring networks. Some comments are made on the rapid expansion of Achnanthidium delmontii sp. nov.
\end{abstract}

Key words: Diatoms, Achnanthidium, Achnanthidium delmontii sp. nov., Languedoc-Roussillon region, France

\section{Introduction}

Round et al. (1990) provided a renewed interest in diatom systematic with the creation of many new genera and also the reappraisal of older genera such as Achnanthidium KüTZING (1844), later more precisely defined by Round \& BUKHTIYAROva (1996). Presently, the Achnanthidium genus includes two groups: a first group with straight terminal raphe endings and a second group with the terminal fissures deflected to the same side of the valve. Following the survey of samples taken from rivers of the Languedoc-Roussillon region in the framework of water quality monitoring, five species with curved raphe fissures were found. One of them, Achnanthidium delmontii, is proposed as a new species. The four others species, Achnanthidium druartii RIMET et CoutÉ, Achnanthidium latecephalum KoBAYASI, Achnanthidium pyrenaicum (HuSDEDT) KoBAYASI and Achnanthidium rivulare PotAPOva et PONADER, present a high percentage of relative abundance in some rivers of this region. A. delmontii sp. nov. was recorded in several rivers of the river water monitoring networks in France. Till now, in routine inventories which aim to monitor biological quality of rivers, $A$. delmontii sp. nov. was misidentified under the name $A$. pyrenaicum, A. pfisteri Lange-Bertalot or non identified to the species level.

This paper presents the morphology, the ecology and the distribution in French rivers of $A$. delmontii sp. nov., compares it to the most closely related species and give information on its rapid expansion.

\section{Material and Methods}

The samples were collected using the French standard NF T 90-354 (AFNOR 2000) in many different rivers of the Languedoc-Roussillon and Rhin-Meuse regions by different public and private organisations in charge of monitoring water quality control networks (ASCONIT Consultants, AQUASCOP, DREAL Languedoc-Roussillon). The diatoms were sampled on natural substrates such as pebbles and stones. The samples were treated by oxidation with hot $40 \%$ hydrogen peroxide and hydrochloric acid and rinsed three times with deionised water. For LM observations, cleaned diatoms were mounted in Naphrax. LM and morphometric measurements were performed with 
a LEICA DM5000B microscope using a 100x oil immersion objective and a LEICA DFC 420 camera. Measurements on Achnanthidium delmontii sp. nov. were taken from 127 individuals. Relative abundance data were based on LM counts of at least 400 valves. For SEM examinations, cleaned diatoms were dried onto glass coverslips attached to aluminium stubs using nail varnish and sputter-coated with a thin layer of platinum. The observations were performed using a JEOL-JSM 6700F and a JEOL JMS 6490. The temporal changes in abundance of $A$. delmontii sp. nov. was analysed using existing collection slides (from consultancy firm F. PERES, ASCONIT Consultants, AQUASCOP and DREAL Languedoc-Roussillon) dating back to 2005 for some of the stations. Physico-chemical data were provided by DREAL Languedoc-Roussillon and by the water agency Rhin-Meuse (Table 1).

\section{Results}

\section{Achnanthidium delmontii Pérès, Le COHU et BARTHÈs Sp. nov.}

\section{Diagnosis}

In microscopio photonico: valvae lineari-ellipticae apicibus non protractis late rotundatis, lineares quoad specimina maxima sed ellipticae quoad specimina minima. Longitudo: 7.3-21.4 $\mu \mathrm{m}$. Latitudo: 3.3-5.1 um. Longitudo/Latitudo ratio: 2.0-4.7. Raphovalva: area axialis angusta lanceolata; area centralis circiter rectangulata margines valvae attingens, interdum una curta stria ab altero latere. Raphe filiformis recta cum poris centralibus distinctis. Striae subparallelae ad parallelas, 20-26 in $10 \mu \mathrm{m}$ usque ad 35 in $10 \mu \mathrm{m}$ ad apices. Araphovalva: valvae plerumque ellipticae. Area axialis acicularis. Striae subparallelae ad parallelas, 18-22 in $10 \mu \mathrm{m}$ usque 25 in $10 \mu \mathrm{m}$ ad apices; plerumque duae striae remotiores in media parte.

In microscopio electronico: raphovalva leviter concava. Rami raphis cum centralibus extremis forma guttulae in externo visu et curvatis ad opposita latera in interno visu. Fissurae terminales raphis curvatae ad idem latus valvae. Area centralis formans fasciam sed interdum una stria composita una ad tres areolas ad alteram marginem frontis valvae. Striae compositae 5-7 quadrangularibus areolis (45-57 in $10 \mu \mathrm{m})$ in valvae fronte et una elongata areola in valvae limbo. Araphovalva: area axialis cum angusto sterno leviter dilatata in media parte. Striae compositae 6-7 areolis (55-61 in $10 \mu \mathrm{m})$ in fronte valvae et una elongata areola in valvae limbo.

In duabus valvis: in interno visu, areolarum hymenes ex parte perforati poris tenuiter elongatis; striae interruptae sunt duabus polis in limbo et hyalina aream circum frontem valvae adest.
Holotype: PC0142667, Laboratoire de Cryptogamie, Muséum d'Histoire Naturelle. Paris, France.

Isotype: BR-4247, Departement de Bryophyta, Thallophyta, Jardin Botanique National de Belgique, Meise, Belgique.

Type locality: Chusclan - Rivière Cèze - France (alt : $34 \mathrm{~m}$; longitude : 1907 854; latitude: 787811,198 - Lambert II)

Etymology: the specific epithet refers to Dominique Delmont, diatomist at DREAL Languedoc-Roussillon.

\section{Description}

LM: valves are linear with rounded apices becoming elliptical in small individuals (Figs 1-68). On the raphe valve, the axial area is narrow. The central area is irregular forming generally a rectangular fascia but a shortened stria can be present on one of the margin side. The raphe is filiform, straight, with distinct central pores. Striae are slightly radial.

On the rapheless valve the axial area is acicular. Striae are parallel to slightly radiate at the apices; in most cases, two striae are slightly more spaced apart in the middle part of the valve.

SEM: externally, the raphe is straight with droplet-like proximal endings spaced about 0.8 $\mu \mathrm{m}$ apart (Figs 69, 70, 74). The terminal fissures are deflected to the same side and terminate on the valve face near the valve margin (Figs 69, $70,75)$. Internally, the proximal raphe endings are curved in opposite directions (Figs 71, 72, 77) and the distal raphe endings terminate in small helictoglossae (Figs 71, 72). The central area is generally irregular, forming a more or less rectangular fascia but can present on one side a shortened stria consisting of one to three areolae (Figs 74, 77). On the raphe valve, the striae are composed of 5 to 7 ( 45 to 57 in $10 \mu \mathrm{m}$ ) more or less rounded areolae (Figs 69, 70). Sometimes, the Voigt fault is marked by a shortened stria (Figs 70, 72). On the rapheless valve, the striae consist of 6 to 7 areolae (55 à 61 in $10 \mu \mathrm{m})$ and two of them are more distant in the middle part of the valve (Figs 73, 76).

On both valves, the areolae are internally occluded by hymenes perforated by delicate slits (Figs 79-82). There is a row of elongated areolae on the mantle (Figs $75,76,78$ ) with a gap at the poles; the mantle elongated areolae are separated from those of the valve face by a hyaline area 

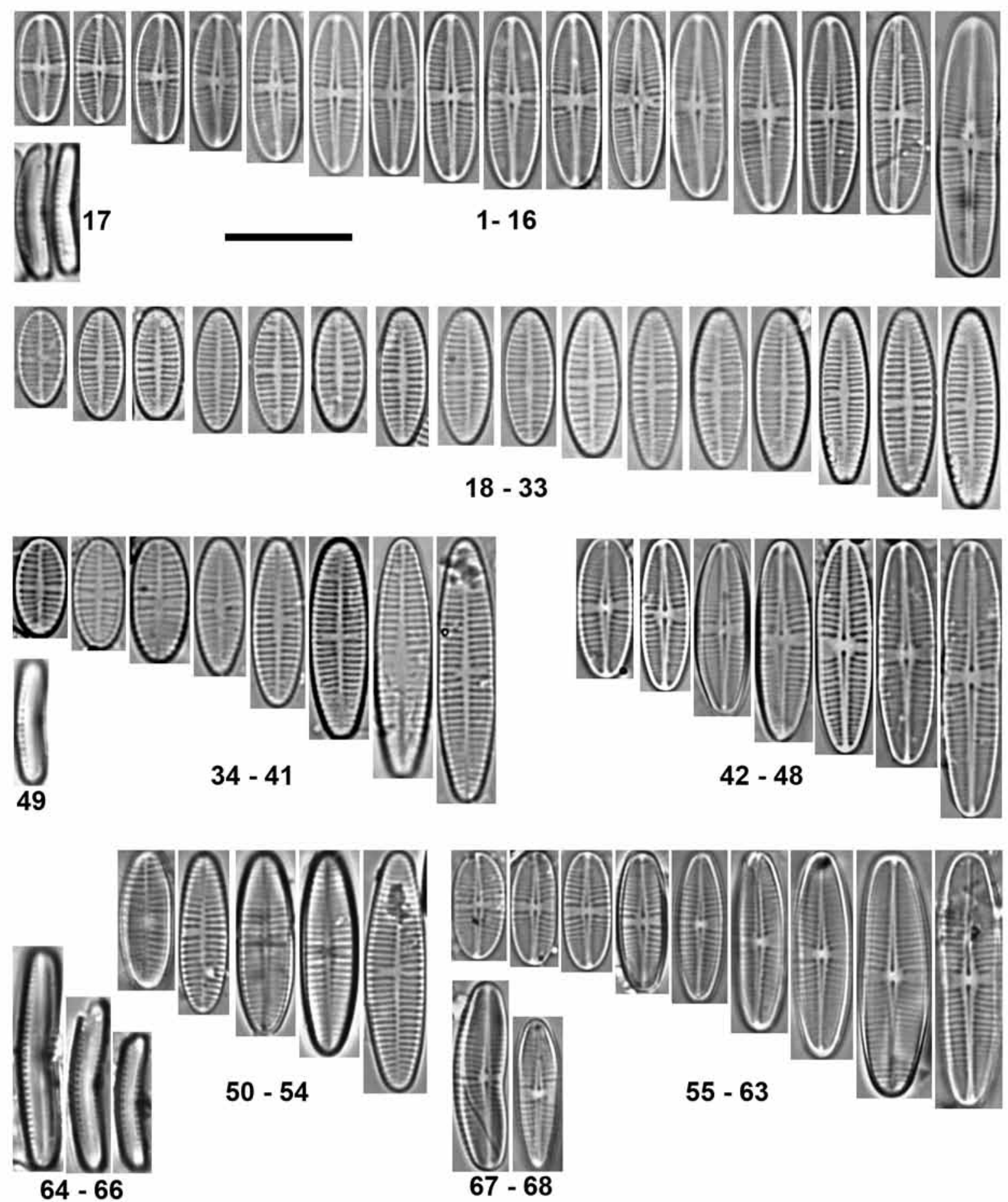

Figs 1-68. Achnanthidium delmontii sp. nov. LM: (1-16) raphe valves; (17) girdle view; (18-33) and rapheless valves from type population (river Cèze at Chusclan); (34-41) rapheless valves; (42-48) raphe valves; (49) and girdle view (river Rhône at Roquemaure); (50 - 54) rapheless valves; (55-63) raphe valves; (64-66) girdle view; (67-68) and abnormal forms (67-68) (river Vieux Rhin at Kembs). Scale bar $10 \mu \mathrm{m}$. 


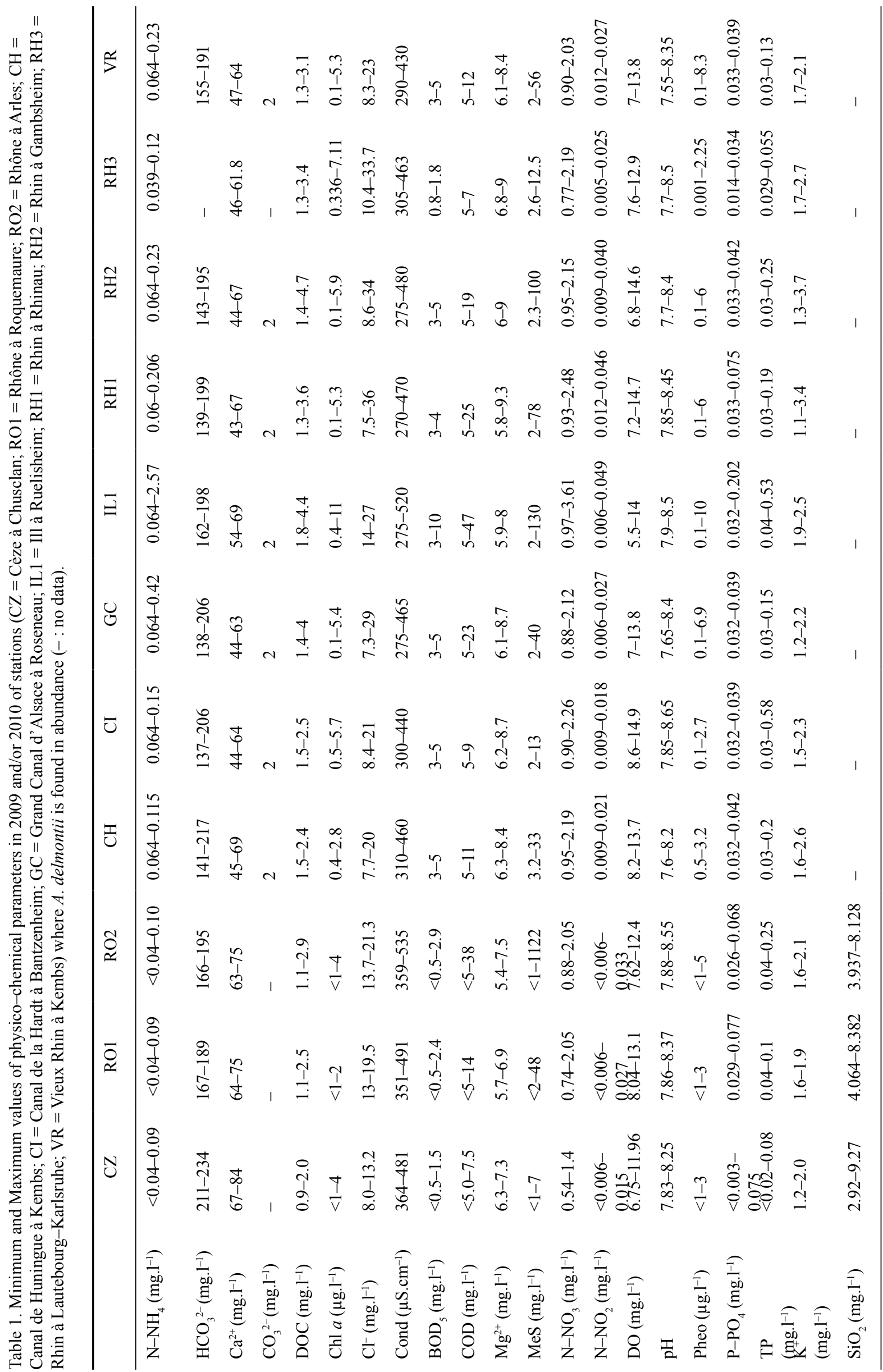




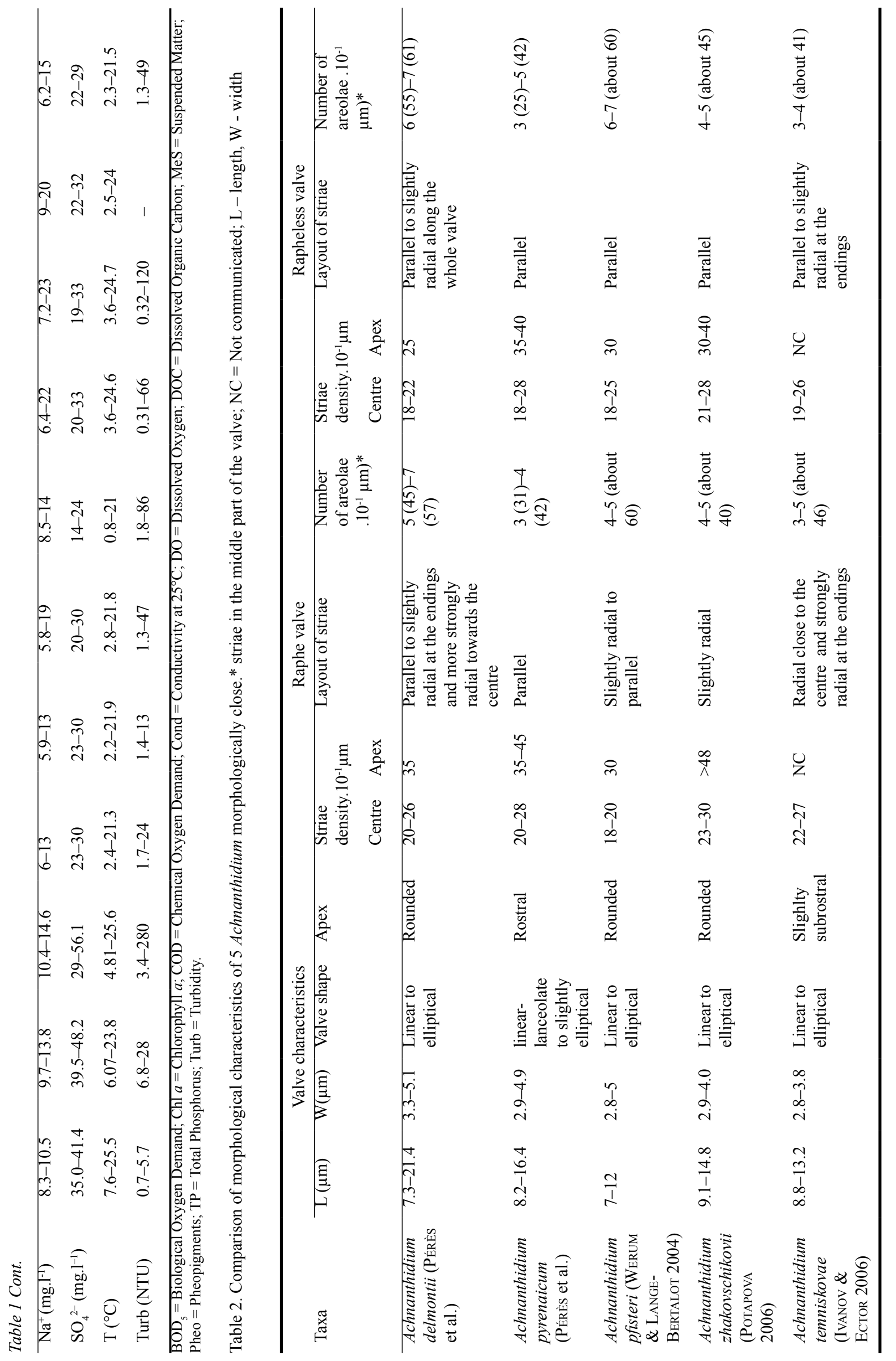



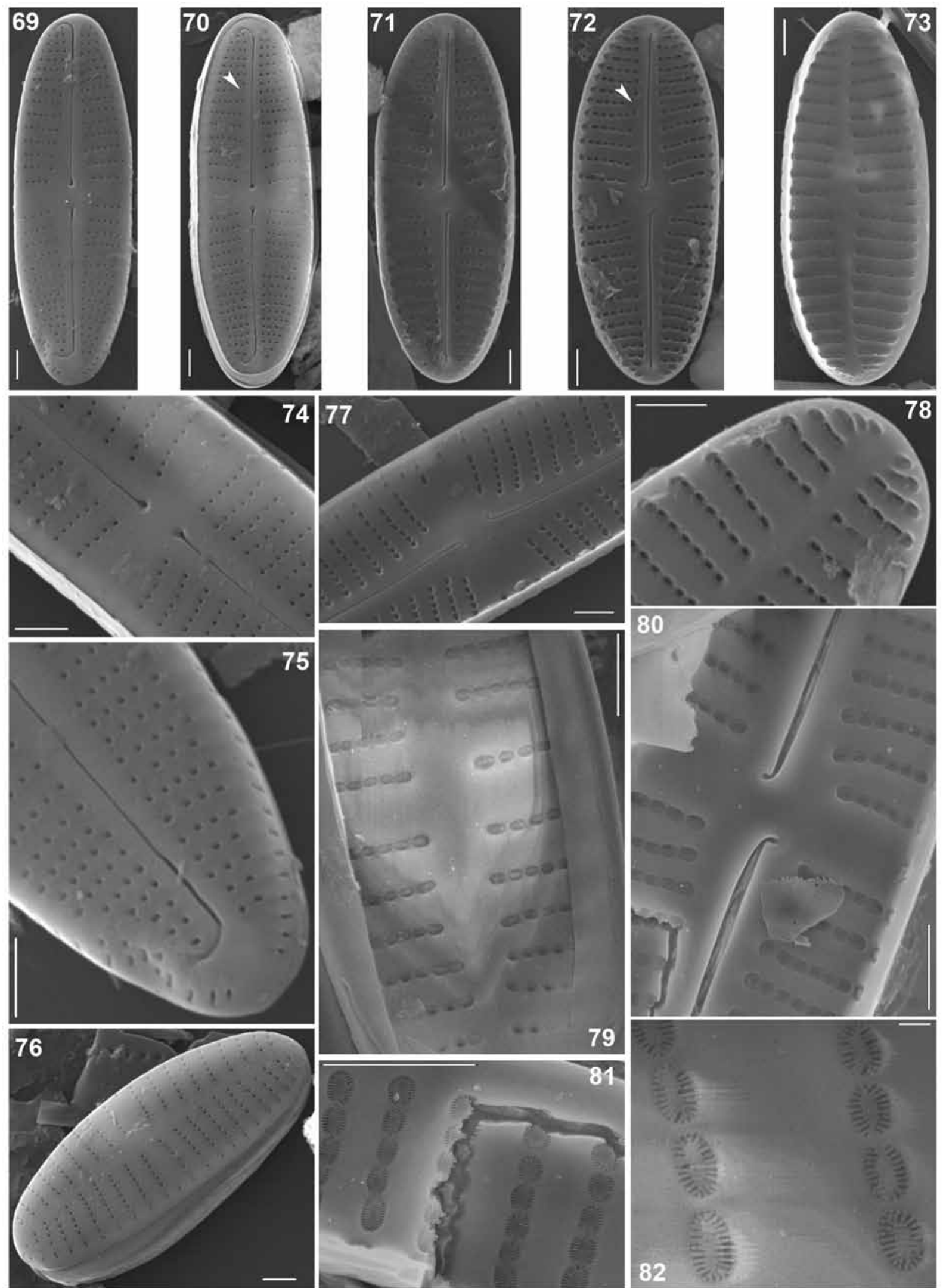
along the edge of the valve face (Figs 75,76 ).

\section{Ecology, associated diatom flora and distribution of Achnanthidium delmontii sp. nov.}

The type population of Achnanthidium delmontii sp. nov., was found in the river Cèze at Chusclan (Gard, Languedoc-Roussillon). It is a Mediterranean river (20 to $50 \mathrm{~m}$ wide), which takes its source in the mountain Cévennes and emerges in the downstream part of the Rhône. The type population of $A$. delmontii has its maximum relative abundance in a location characterized by an alkaline $\mathrm{pH}$, high conductivity and calcium concentration (Table 1). The $\mathrm{PO}_{4}-\mathrm{P}^{-}$level in the river Cèze at Chusclan (maximum $\mathrm{PO}_{4}-\mathrm{P}^{-}$ concentration: $75 \mu \mathrm{g} .1^{-1}$ ) indicates an eutrophic environment (Table 1). These values are quite close to those observed for $A$. latecephalum and $A$. druartii (see also Rimet et al. 2010) in the Languedoc-Roussillon region. When A. delmontii was strongly dominant $(75 \%)$ in the river Cèze at Chusclan, it was associated with Amphora pediculus (KüTZING) Grunow (4\%), Achnanthidium minutissimum (KüTZING) CZARNeCKI (4\%), Navicula cryptotenella LANGEBertalot (3\%) and Gomphonema minutum Agardh (2\%). The associated taxa are mainly $\beta$-mesosaprobe and eutrophic, according to VAN DAm et al. (1994), which tend to corroborate the chemical data (Table 1).

A. delmontii appears for the first time in 2007 (Fig. 85) with a low percentage of relative abundance $(<1 \%)$ in one sample: Vieux Rhin in Kembs (VR). In the type location (CZ), $A$. delmontii appears from 2008 and after that,

Figs 69-82. Achnanthidium delmontii sp. nov. SEM: (69) external view of the raphe valve; (70) external view of the raphe valve showing a voigt fault (arrowhead); (71) internal view of the raphe valve; (72) internal view of the raphe valve showing a voigt fault (arrowhead); (73) internal view of the rapheless valve; (74) external view of central area with shortened stria composed of one areola; (75) external view of raphe valve showing the terminal fissures and the interruption of the striae at the end; (76) external view of the rapheless valve showing the hyaline area; (77) internal view of central area showing the raphe proximal endings deflected in opposite side; (78) internal view of the rapheless valve showing the interruption of the striae at the end; (79) internal view of the rapheless valve showing the areolae structure; (80) internal view of the raphe valve showing the areolae structure; (81) internal view of the raphe valve areolae; (82) internal view of the rapheless valve areolae. Scale bars $1 \mu \mathrm{m}$ (69-81), $100 \mathrm{~nm}(82)$. proliferates $(>60 \%)$. At the same period, $A$. delmontii is observed for the first time in rivers such as Canal de Huningue (CH), Canal de NeufBrisach $(\mathrm{CN})$, Canal de la Hardt $(\mathrm{CH})$, Ehn (EH), Grand Canal d'Alsace (GC), Ill (IL1 and IL2), Lertzbach (LB), Muhlbach de la Hardt (MH), Quatelbach (QB), Rhin (RH1, RH2, RH3), Vieux Rhin (VR), Rhône (RO1 and RO2) and Cèze (CZ) (Fig. 85). The rapid expansion of A. delmontii seems to correspond to the criteria defined by Coste \& ECTOR (2000) which qualify invasive species (recent appearance, proliferation, rapid expansion).

\section{Discussion}

In LM, Achnanthidium delmontii sp. nov. most closely resembles $A$. pfisteri LANGe-Bertalot (Werum \& LANGe-Bertalot 2004). A. delmontii is much longer than $A$. pfisteri (7.3-21.4 $\mu \mathrm{m}$ vs 7-12 $\mu \mathrm{m}$, Table 2) and has a higher number of striae on the raphe valve (20-26 vs $18-20$ in $10 \mu \mathrm{m}$, Table 2). Moreover, in $A$. delmontii, the raphe valve has a well delimited fascia in most cases whereas in $A$. pfisteri, the central area is asymmetrical (WERUM \& Lange-Bertalot 2004, plate 20, figs 12-13). In SEM, the terminal fissures, deflected to the same side, are much shorter in A. pfisteri than in A. delmontii. On the raphe valve, the number of areolae per stria is higher in A. delmontii (Table 2 ). The mantle areolae row is interrupted at the apices on the rapheless valve in $A$. delmontii whereas it is continuous in $A$. pfisteri (Werum \& LANGE-Bertalot 2004, plate 20, fig. 14).

In LM, the presence of a fascia on the raphe valve is a feature shared by $A$. delmontii and $A$. temniskovae IVANOv et ECTOR (IVANOv \& ECTOR 2006, figs 1-11). Otherwise, both species can be distinguished by the valve morphology and the dimensions (Table 2). In SEM, the raphe valve striae are subparallel towards the apices in $A$. delmontii whereas they are strongly radiate in A. temniskovae (IvANOv \& ECTOR 2006, figs $27,28)$. The number of areolae per stria is very different in both species and, moreover, the row of mantle areolae does not stop at the apices in $A$. temniskovae, unlike $A$. delmontii.

In LM, A. delmontii and A. zhakovschikovii Potapova (Potapova 2006) have linear to elliptic valves with rounded apices. Both species differ in 

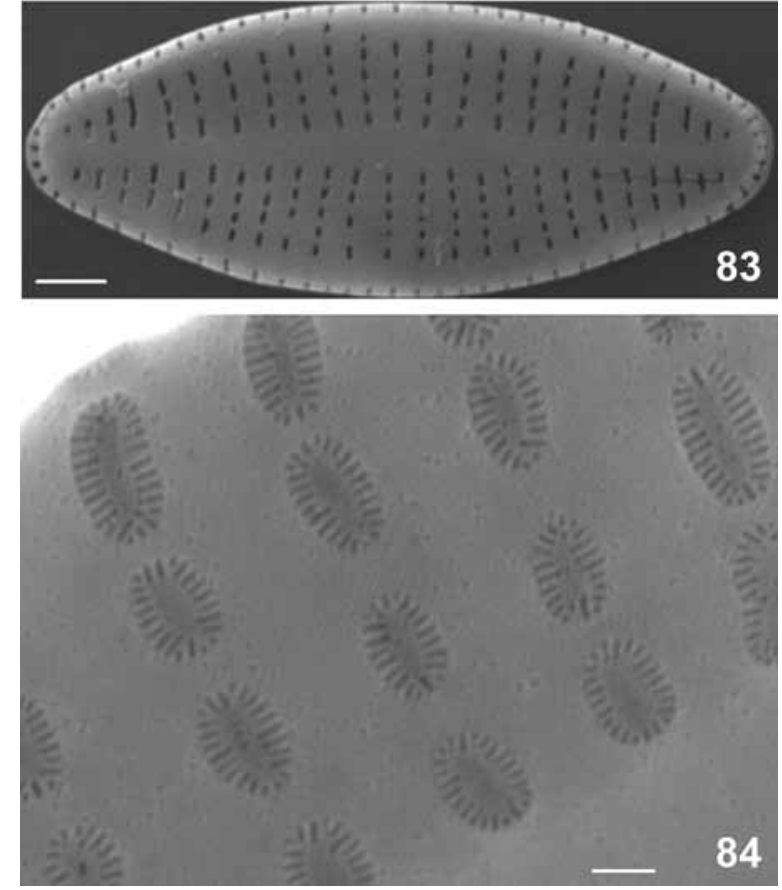

Fig. 83. External view of rapheless valve of Achnanthidium pyrenaicum, SEM, Rebenty river, France. Scale bar $1 \mu \mathrm{m}$. Fig. 84. Internal view of the rapheless valve areolae of Achnanthidium latecephalum, SEM, river Hérault, France. Scale bar $100 \mathrm{~nm}$.

the dimensions (Table 2) and the number of striae on the raphe valve, ranging from 20 to 26 in $A$. delmontii and from 23 to 30 in A. zhakovschikovii (Table 2). Moreover, on the rapheless valve the configuration of the axial area is different (PotAPOVA 2006, figs 2, 6, 7). In SEM, the curved terminal fissures are shorter in A. zhakovschikovii (Potapova 2006, fig. 30) than in A. delmontii. The number of areolae per stria is lower in $A$. zhakovschikovi on both valves (Table 2). The raphe valve areolae are more or less rounded in $A$. delmontii whereas they are transapically elongated slits in A. zhakovschikovii (РОTAPOvA 2006, fig. 30). Moreover, A. delmontii differs from A. zhakovschikovii (РотAPOva 2006, fig. 31) by the interruption of the mantle striae row on the rapheless valve at the apices.

In LM, A. delmontii can be differentiated from $A$. pyrenaicum by the valve morphology (KoBAYASI 1997, figs 3-6; Potapova \& Ponader 2004, fig. 105). A. delmontii is characterized by a fascia on the raphe valve (Figs 1-16) whereas the central area is asymmetrical with often a stria on one side in $A$. pyrenaicum (KoBayasi 1997, fig. 11; Potapova \& Ponader 2004, fig. 105). Length being equal, $A$. delmontii is wider than $A$. pyrenaicum (personal observation). In SEM, in external view, the areolae are rounded on both valves in $A$. delmontii whereas they are transapically elongated in A. pyrenaicum (Fig. 83, Kobayasi 1997, fig. 15; Potapova \& Ponader 2004, figs 105, 106). On both valves, $A$. delmontii has 5 to 7 areolae per stria against only 3 to 4 in A. pyrenaicum (Table 2). On the rapheless valve, the row of mantle striae is interrupted at the apices in A. delmontii (Fig. 78) whereas it is continuous in A. pyrenaicum (Fig. 83).

To conclude, we draw attention to the detailed ultrastructure of the areolae. A. delmontii (Fig. 82), A. latecephalum (Fig. 84), A. convergens (Kobayasi) Kobayasi (KobaYasi 1997, fig. 68) and A. japonicum (Kobayasi) Kobayasi (Kobayasi et al. 2006, pl. 155, figs 17, 18) have areolae internally occluded by hymenes perforated by delicate slits. A few Achnanthidium species with straight raphe such as $A$. saprophilum (KoBayasi et MaYama) Round et BukHTIYARova (LANGe-Bertalot \& Krammer 1989, plate 56, fig. 8; Kobayasi et al. 2006, pl. 161, fig. 17) and A. pusillum (Grunow) CZARNECKi (KobaYAsi et al. 2006, pl. 158, fig. 14) show areolae with a cribrum. This feature is possibly another criterion to separate both Achnanthidium groups. Nevertheless, further investigation is required.

\section{Aknowledgements}

Material examined from Languedoc-Roussillon region was obtained in the framework of the research programme "Atlas des Diatomées de LanguedocRoussillon ». Financial support for this research programme was provided by DREAL LanguedocRoussillon. We gratefully acknowledge C. Deshayes and S. Le Blond-Duplouy for technical assistance with SEM, Agnès Pierret and Florence Barange for the illustrations, Catherine Vignon for the English translation and Aquascop for providing biological material.

\section{References}

AfNOR, (2000): Norme AFNOR NF T90-354. Détermination de l'Indice Biologique Diatomées (IBD), June 2000, pp. 63.

Coste, M. \& Ector, L. (2000): Diatomées invasives exotiques ou rares en France: principales observations effectuées au cours des dernières décennies. - Systematics and Geography of Plants 70: 373-400.

Ivanov, P. \& Ector, L. (2006): Achnanthidium 


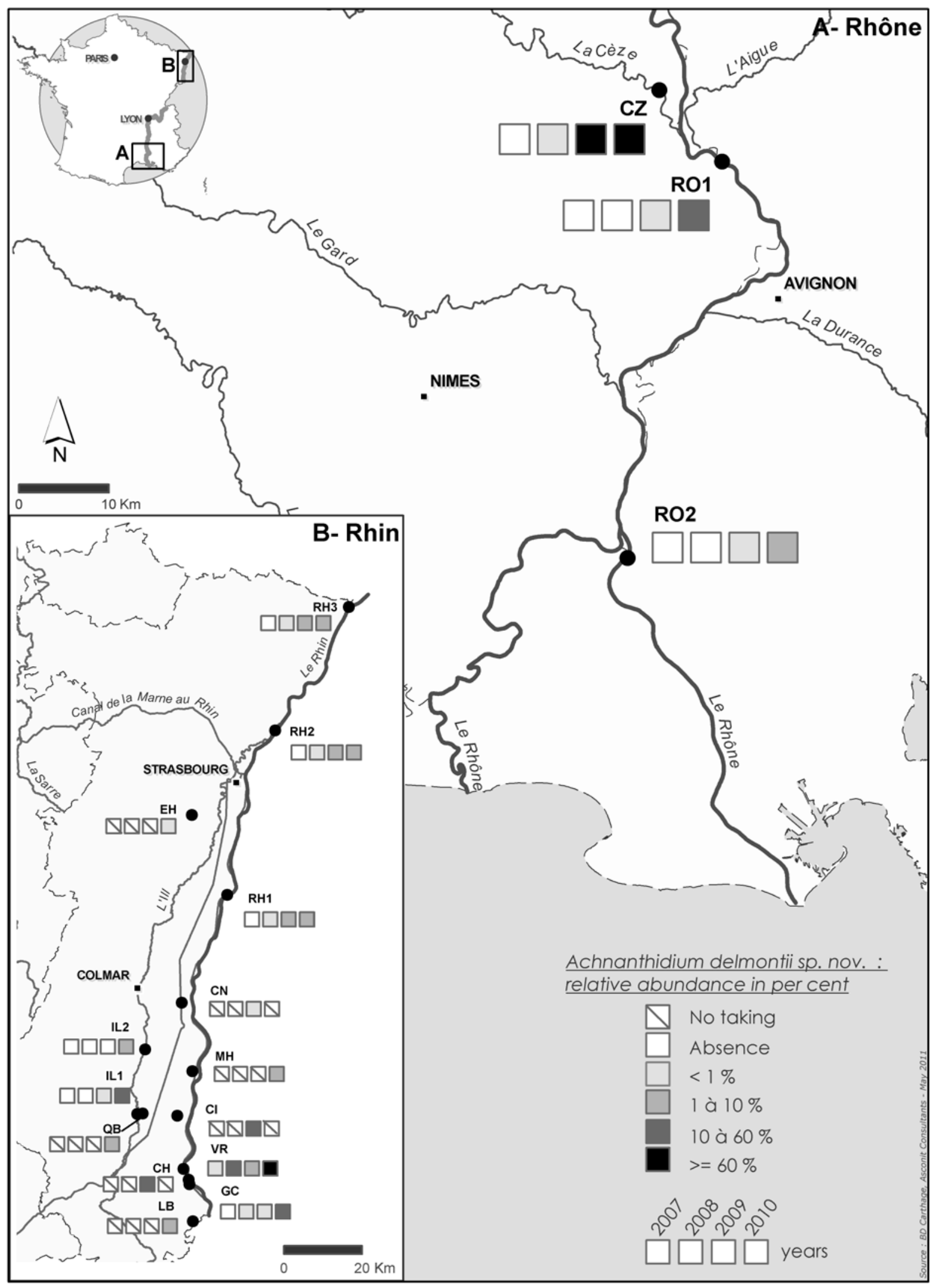

Fig. 85. Distribution and temporal changes of Achnanthidium delmontii sp. nov. in percentage of relative abundance from 2007 to 2010 . 
temniskovae sp. nov., a new diatom from the Mesta River, Bulgaria. - In: OGNJANOvARumenova, N. \& Manoylov, K. (ed.): Advances in phycological studies, Festschrift in Honour of Prof. Dobrina Temniskova-Topalova. pp.147-154, Pensoft, Sofia-Moscou, Russie.

Kobayasi, H. (1997): Comparative studies among four linear-lanceolate Achnanthidium species (Bacillariophyceae) with curved terminal raphe endings. - Nova Hedwigia 65: 147-163.

Kobayasi, H.; Idei, M.; Mayama, S.; Nagumo, T. \& Osada, K. (2006): H. Kobayasi's Atlas of Japanese Diatoms based on electron microscopy. - 531 pp., Uchida Rokakuho Publishing Co., Ltd, Tokyo.

KützING, F.T. (1844): Die Kieselschaligen. Bacillarien oder Diatomeen. Nordhausen. - 152 pp., 30 pls.

Lange-Bertalot, H. \& Krammer, K. (1987): Bacillariaceae, Epithemiaceae, Surirellaceae. Neue und wenig bekannte Taxa, neue Kombinationen und Synonyme, sowie Bemerkungen und ergänzungen $\mathrm{zu}$ den Naviculaceae. - Bibliotheca Diatomologica 15:1-289.

Potapova, M. \& Ponader, K.C. (2004): Two common North American diatoms, Achnanthidium rivulare sp. nov. and $A$. deflexum (Reimer) Kingston : morphology, ecology and comparison with related species. - Diatom Research 19: $33-57$.
Potapova, M. (2006): Achnanthidium zhakovschikovii sp. nov. (Bacillariophyta) and related species from rivers of Northwestern Russia. - Nova Hedwigia 82: 399-408.

Rimet, F.; Couté, A.; Piuz, A.; Berthon, V. \& Druart, J.C. (2010): Achnanthidium druartii sp. nov. (Achnanthales, Bacillariophyta): A new species invading European rivers. - Vie et Milieu-Life and Environment 60: 185-195.

Round, F.E.; Crawford, R.M. \& Mann, D.G. (1990): The Diatoms - Biology \& Morphology of the genera. - 747 pp., Cambridge University Press, Cambridge, Reprinted 2000.

Round, F.E. \& Bukhtiyarova, L. (1996): Four new genera based on Achnanthes (Achnanthidium) together with a re-definition of Achnanthidium. - Diatom Research 11: 345-361.

Van Dam, H.; Mertens, A. \& Sinkeldam, J. (1994): A coded checklist and ecological indicator values of freshwater diatoms from the Netherlands. - Netherlands Journal of Aquatic Ecology 28: 117-133.

Werum, M. \& Lange-Bertalot, H. (2004): Diatoms in springs from Central Europe and elsewhere under the influence of hydrogeology and anthropogenic impacts. - Iconographia Diatomologica 13: 3-417.

(C) Czech Phycological Society (2012)

Received May 30, 2011

Accepted August 26, 2011 